\title{
RESPIRATORY PROBLEMS IN COTTON MILL WORKERS
}

\author{
Ravi Dosi ${ }^{1}$, Arpit Jain $^{2}$, Priyanshu Jain ${ }^{3}$, Gaurav Jain ${ }^{4}$, Prakash Joshi ${ }^{5}$, Saurabh Karnawat ${ }^{6}$, Arun Chandelkar ${ }^{7}$, Garima Singh Rawat ${ }^{8}$
}

${ }_{1}^{1}$ Associate Professor and HOD, Department of Pulmonary Medicine, SAIMS, Indore, Madhya Pradesh, India.

${ }^{2} 3^{\text {rd }}$ Year Resident, Department of Pulmonary Medicine, SAIMS, Indore, Madhya Pradesh, India.

32nd Year Resident, Department of Pulmonary Medicine, SAIMS, Indore, Madhya Pradesh, India.

${ }_{41}$ st Year Resident, Department of Pulmonary Medicine, SAIMS, Indore, Madhya Pradesh, India.

${ }^{5}$ Senior Resident, Department of Pulmonary Medicine, SAIMS, Indore, Madhya Pradesh, India.

${ }^{63 r d}$ Year Resident, Department of Radiation Medicine, SAIMS, Indore, Madhya Pradesh, India.

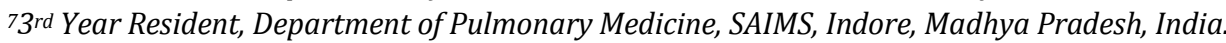

${ }^{81} 1^{\text {st }}$ Year Resident, Department of Obstetrics and Gynaecology, SBKS Medical College, Vadodara, India.

ABSTRACT

\section{BACKGROUND}

Cotton textile workers are at increased risk of respiratory symptoms such as chest tightness, chronic bronchitis and loss of pulmonary function due to inhalational exposure to cotton dust. Indore has been a hub of textile manufacturing from past 30 - 40 years and a large subset of population is employed in textile manufacturing.

An observational study was conducted on 200 subjects in the suburbs of Indore city to compare prevalence of respiratory problems among cotton mill workers and unexposed individuals.

\section{MATERIALS AND METHODS}

Universal sampling method was used to decide sample size. Statistical analysis was done using SPSS 20.0 version. Continuous variables are presented as mean SD. Categorical variables are expressed as frequencies and percentages. Chi-square test is used for the determination of association between two qualitative variables and independent sample t-test will be used for evaluation of difference between means. A p-value of less than 0.05 will be taken to indicate significant difference.

\section{RESULTS}

Cotton mill workers were predominantly found to have COPD Stage 2 and 3 which was seen in $70 \%$ of the subjects and Bronchial Asthma seen in $30 \%$ of the subjects.

\section{CONCLUSION}

Study showed that respiratory symptoms and pulmonary function abnormalities are seen more frequently in cotton workers compared to controls. It can be concluded from the study that more aggressive measures must be taken in the workplace with regular sampling of the workplace and regular medical check-up of all cotton mill workers should be done to prevent the harmful respiratory effect of cotton dust exposure on lung function.

\section{KEY WORDS}

American Thoracic Society (ATS) Questionnaire, Chronic Obstructive Pulmonary Disease (COPD), Pulmonary Function Test (PFT), $\mathrm{FEV}_{1}, \mathrm{FVC}$.

HOW TO CITE THIS ARTICLE: Dosi R, Jain A, Jain P, et al. Respiratory problems in cotton mill workers. J. Evolution Med. Dent. Sci. 2018;7(38):4230-4233, DOI: $10.14260 /$ jemds/2018/944

\section{BACKGROUND}

The Indian textile industry continues to be the second-largest employment generating sector in India.(1,2) Survey on cotton mill suggests that there are about 1962 cotton textile mills in India, of which $80 \%$ are in the private sector and the rest in the public and cooperative sector. Apart from these, there are several thousand small factories with three to ten looms. ${ }^{(3,4)}$

Cotton textile workers are at risk of respiratory symptoms such as chest tightness, chronic bronchitis and loss of pulmonary function due to inhalational exposure to cotton dust.

'Financial or Other Competing Interest': None.

Submission 28-02-2018, Peer Review 01-09-2018,

Acceptance 07-09-2018, Published 17-09-2018.

Corresponding Author:

Dr. Ravi Dosi

Dosi Bhawan, Post Office Road,

124, Tilak Nagar Main,

Indore-452018, Madhya Pradesh, India.

E-mail: ravi.dosi@gmail.com

DOI: $10.14260 /$ jemds $/ 2018 / 944$
The acute respiratory response to cotton dust has been described in many studies. The acute airway response is described as a cross-shift drop in forced expiratory volume in $1 \mathrm{~s}\left(\mathrm{FEV}_{1}\right)$ with or without respiratory complaints. It is considered that acute response is reversible after short-term exposure, but chronic effects may result from prolonged exposure.(5) About $25-45 \%$ of patients with Chronic Obstructive Pulmonary Disease (COPD) worldwide have never smoked. This is the contribution of workplace exposures to obstructive lung disease. While a number of non-tobacco related environmental exposures may cause COPD, textile industry makes major bulk of it. Around 60 million people are employed in the textile or clothing industry worldwide, while textile industry in India provides direct employment to around 35 million people, being the second largest employment generating sector in India.[1,3] $\mathrm{A}$ cotton mill is a factory, housing powered spinning or weaving machinery for the production of yarn or cloth from cotton.

The modern Indian mechanised textile industry was born in 1854, when a steam-powered mill was opened in Bombay by Cowasjee N. Davar; however, a large share of Indian 
Cotton Industry remained handloom dependent. Workers in cotton industry, more so in handloom sector, are exposed to variety of air-borne agents, originating from natural fibrous materials and dust in their work environment. [6] Thus, they are at risk of respiratory symptoms and loss of pulmonary function due to inhalational exposure to cotton dust.[5] Noninvasive methods such as Pulmonary Function Tests (PFTs) can be used for the assessment of respiratory disorders due to cotton dust exposure; however, the long-term effects of exposure to cotton dust using an accurate objective measurement is not well-understood. This prospective study of 100 cotton mill workers from Malwa Mills of Indore, Madhya Pradesh, was designed to evaluate the long-term respiratory diseases due to non-synthetic textile work, i.e. cotton in the context of disease classifications such as reversible or irreversible obstructive lung disease. This study compares lung function between cotton mill workers and control group to identify and compare prevalence of obstructive lung disease in both the groups of Malwa Mill Area at Indore.

\section{MATERIALS AND METHODS}

It is a descriptive comparative study. All workers and residents of Malwa Mill area, Indore were interviewed and examined by the pulmonologist. A pilot study was conducted in 10 patients with pre-tested and semi-structured questionnaire. The questionnaire was modified accordingly. It included questions on personal information, respiratory symptoms and work history. Personal information included name, age and history of smoking and tobacco chewing. Respiratory symptoms such as dyspnoea, cough and chest tightness were documented. All subjects examined were advised for complete workup at Medical College.

\section{Place of Study}

Sri Aurobindo Medical College and PG Institute.

\section{Study Design}

A cross-sectional descriptive comparative study.

Study Period- July 2016 to July 2017.

\section{Study Duration- 12 months.}

The study population consisted of 100 cotton textile workers who were exposed to airborne cotton dust and employed more than 9 years in cotton textile mills in Indore, Madhya Pradesh. 100 unexposed subjects who were relatives of workers or the people living in same area, i.e. Malwa Mill area in Indore, were taken as the control group. Subjects were excluded from the study if they had history of respiratory diseases such as asthma, bronchitis, emphysema, bronchiectasis, lung cancer or any other chronic condition and smokers. The study was conducted at Sri Aurobindo Medical College under Respiratory Medicine Department.

\section{The Sample Size required was taken for Convenience}

A modified version of the American Thoracic Society (ATS), respiratory symptoms questionnaire was completed for each worker.[7] All workers were interviewed and examined by the pulmonologist.
PFTs and chest radiography were conducted for all subjects. PFTs were carried out by a trained technician using a calibrated spirometry (Jaeger). The highest values for FEV 1 and Forced Vital Capacity (FVC) after three acceptable manoeuvres according to ATS criteria were used in subsequent analysis.[8]

According to ATS criteria, in the cases with obstructive pattern, changes in $\mathrm{FEV}_{1}$ and FVC were measured before and 20 mins after the separate inhalation of four puffs of $250 \mu \mathrm{g}$ salbutamol from a metered-dose inhaler. Patients rested for 20 mins after the first measurement.

\section{Statistical Analysis}

Statistical analysis was done with the statistical package for the Social Science System Version SPSS 20.0. Data was analysed and quantitative and qualitative variables were measured. Continuous variables were presented as mean SD. Categorical variables will be expressed as frequencies and percentages. Chi-square test was used for the determination of association between two qualitative variables, while independent sample t-test was used for evaluation of difference between means, both in exposed and unexposed groups. For all statistical tests, a p value less than 0.05 will be taken to indicate a significant difference.

\section{RESULTS}

All 100 exposed (cotton workers) and 100 unexposed individuals underwent an interview, physical examination, assessment of PFTs and radiographic results by a pulmonologist.

A total of $51 \%$ and $31 \%$ of the cotton textile workers had one or more respiratory symptoms and respiratory signs, respectively. Table 1 summarizes the prevalence of respiratory complaints and PFTs of both groups. The prevalence of cough, sputum and chest tightness were statistically significant $(<0.001)$ between two groups.

PFTs were performed for all subjects. Statistically significant $(<0.001)$ decrease in $\mathrm{FEV}_{1}, \mathrm{FVC}$ and $\mathrm{FEV}_{1} / \mathrm{FVC}$ were noted in cotton workers when compared with the control group [Table 1]. Twenty-eight percentage of subjects in the exposed group and $5 \%$ of subjects in the unexposed group had an obstructive pattern. Overall, 25\% (7/28) of exposed group with airway obstructive pattern on PFT showed reversibility after post-bronchodilator test.

\begin{tabular}{|c|c|c|c|}
\hline & $\begin{array}{c}\text { Cotton Workers } \\
\text { (Case) }\end{array}$ & Controls & P \\
\hline \multicolumn{4}{|c|}{ Respiratory Symptoms } \\
\hline Cough & 47 & 10 & $<0.001$ \\
\hline Dyspnoea & 15 & 9 & 0.19 \\
\hline Chest Tightness & 26 & 7 & 0.002 \\
\hline Chest Pain & 14 & 6 & 0.24 \\
\hline Sputum & 41 & 5 & $<0.001$ \\
\hline \multicolumn{4}{|c|}{ Respiratory Signs } \\
\hline Wheeze & 20 & 4 & $<0.001$ \\
\hline Crackles & 14 & \\
\hline \multicolumn{4}{|c|}{ Pulmonary Function Tests } \\
\hline FEV1 & $3.02+/-0.66$ & $3.45+/-0.53$ & $<0.001$ \\
\hline FVC & $3.62+/-0.59$ & $4.22+/-0.50$ & $<0.001$ \\
\hline FEV1/FVC & $0.72+/-0.07$ & $78+/-0.04$ & $<0.001$ \\
\hline \multicolumn{4}{|c|}{ Table 1 } \\
\hline
\end{tabular}




\section{DISCUSSION}

Cotton dust is defined as dust generated into the atmosphere as a result of processing the cotton fibers combined with any naturally occurring materials such as stems, leaves, bracts and inorganic matter which may have accumulated on the cotton fibers during growing and harvesting period.(9) Most studies in cotton and hemp workers report an increased incidence of chronic and progressive dyspnoea, cough and sputum production characteristic of symptoms seen in COPD. $(10,11,12,13,9)$

Mechanism of lung function abnormality, specific pathogenesis is not known. Suryakar et al found that oxidative stress may contribute to respiratory disorders in cotton mill workers. As duration of exposure is increased, the effect was enhanced. Long-term exposure to cotton dust results in macrophage/ neutrophil migration into the airspaces, which generate reactive oxygen species production by opsonisation.(14) According to Lai and Christiani, organic dust exposure in the textile industry leads to obstructive lung disease that has features of both asthma and COPD. An inversion of the pulmonary macrophage: dendritic cell ratio may be a mechanistic explanation for persistent inflammation and obstructive lung disease seen in endotoxin-related textile exposures. One study showed that the prevalence of respiratory symptoms being higher in smokers than nonsmokers.(15) Smoking has an additive effect on cotton dust exposure.

Dust present during the handling and processing of cotton is considered cotton dust. This dust is a complex mixture of components which may include ground-up plant matter, cotton fiber, bacteria, fungi, soil or pesticides. It may also include other contaminants that have accumulated during the growing, harvesting and subsequent processing or during storage periods.

Occupational exposure to cotton dust can also induce acute airway responses such as byssinosis. Byssinosis is characterised by feeling of shortness of breath and chest tightness on the $1^{\text {st }}$ day of the working week. There may be increased cough and sputum production. In the early stages of byssinosis, these symptoms subside by the end of the workday and reoccur on Monday morning after being away from the dust for a period.

As the length of exposure increases over the working years of the employee, symptoms of the chest tightness and shortness of breath occur more frequently and on all workdays. It is believed that the degree or severity of response for individuals with symptoms of is related to the dust level in the workplace. The beginning steps in yarn preparation generally produce more dust. Therefore, the closer to the beginning of the process, the higher will be the dust level and the more likely the pulmonary reaction or response for some workers.[16]

In this study, cotton industry workers reported a higher prevalence of respiratory symptoms namely cough, dyspnoea, chest tightness, chest pain, sputum, more than unexposed individuals. Results of our survey were in line with previously published studies that reported higher prevalence of respiratory symptoms in cotton workers. Prevalence of respiratory symptoms in cotton workers is similar to that reported by other studies namely Wang et al, 17 Altin et $\mathrm{al},{ }^{18}$ Bünger et $\mathrm{al}^{19}$ and Christiani et $\mathrm{al}^{20}$ The characteristic respiratory symptoms such as chest tightness and cough have been standardised by Schilling et al. ${ }^{21}$ In our study, the most common respiratory symptoms were cough and sputum production. These symptoms probably represent variants of the airway irritation because of dust inhalation.

\begin{tabular}{|c|c|c|c|}
\hline $\begin{array}{c}\text { Respiratory } \\
\text { Symptoms }\end{array}$ & $\begin{array}{c}\text { Cotton Workers } \\
\text { (Case) }\end{array}$ & Controls & $\mathbf{P}$ \\
\hline Cough & 47 & 10 & $<0.001$ \\
\hline Dyspnoea & 15 & 9 & 0.19 \\
\hline Chest Tightness & 26 & 7 & 0.002 \\
\hline Chest Pain & 14 & 6 & 0.24 \\
\hline Sputum & 41 & 5 & $<0.001$ \\
\hline
\end{tabular}

Our study also showed higher prevalence of respiratory signs namely wheezes and crackles in Cotton Mill workers as compared to unexposed individuals.

\begin{tabular}{|c|c|c|c|}
\hline $\begin{array}{c}\text { Respiratory } \\
\text { Signs }\end{array}$ & $\begin{array}{c}\text { Cotton Workers } \\
\text { (Case) }\end{array}$ & Controls & P \\
\hline Wheeze & 20 & 4 & $<0.001$ \\
\hline Crackles & 14 & & \\
\hline
\end{tabular}

We also found that cotton industry workers had lower predicted $\mathrm{FEV}_{1} \%$ and $\mathrm{FEV} 1 / \mathrm{FVC}$ values as compared to the group of unexposed individuals. Previous studies like Lai, et $\mathrm{al}^{22}$ and Wang et $\mathrm{al}^{23}$ also had similar findings. Trupin et al ${ }^{24}$ observed accelerated decline in $\mathrm{FEV}_{1}$ in cotton workers as compared to the control group, even in non-smokers and after retirement.

\begin{tabular}{|c|c|c|c|}
\hline $\begin{array}{c}\text { Pulmonary } \\
\text { Function Tests }\end{array}$ & $\begin{array}{c}\text { Cotton Workers } \\
\text { (Case) }\end{array}$ & Control & P \\
\hline FEV1 & $3.02+/-0.66$ & $3.45+/-0.53$ & $<0.001$ \\
\hline FVC & $3.62+/-0.59$ & $4.22+/-0.50$ & $<0.001$ \\
\hline FEV1/FVC & $0.72+/-0.07$ & $78+/-0.04$ & $<0.001$ \\
\hline
\end{tabular}

The physiological picture suggested predominantly obstructive pattern, which was seen in $28 \%$ of cases in our study, which was in line with previously conducted studies Aminian et al $^{25}$ and Kobayashi et al, ${ }^{26}$ though restrictive or mixed pattern may also be found in some cotton mill workers.

According to our study, it can be concluded that cotton mill workers are at higher risk for developing respiratory symptoms, signs and loss of pulmonary function when exposed to cotton dust for a longer period, which is consistent with other studies namely Shi et $\mathrm{al}^{27}$ and Chattopadhyay et al.28

\section{CONCLUSION}

Our study shows that respiratory symptoms and pulmonary function abnormalities are seen more frequently in cotton workers compared to controls. The study shows that as the duration of exposure increased, symptoms increased. Lung function abnormality was present even in absence of exposure. This suggests that more aggressive measures must be taken in the workplace. Sampling of the workplace must be done at regular intervals. Regular medical check-ups of all cotton mill workers should be done to prevent the harmful respiratory effect of cotton dust exposure on lung function. 


\section{REFERENCES}

[1] Forstater M. Implications of the global financial and economic crisis on the textile and clothing sector. International Labour Organization: Sectoral coverage of the global economic crisis. 2009: p. 1-26.

[2] A brief history of Textile Industry in India, January, 2010" Archived from the original (PDF) on 22 May 2012.

[3] Salvi SS, Barnes PJ. Chronic obstructive pulmonary disease in non-smokers. Lancet 2009;374(9691):73343.

[4] "Number of Cotton Mills in India" (PDF).

[5] Wang XR, Zhang HX, Sun BX, et al. A 20-year follow-up study on chronic respiratory effects of exposure to cotton dust. Eur Respir J 2005;26(5):881-6.

[6] Anyfantis ID, Rachiotis G, Hadjichristodoulou C, et al. Respiratory symptoms and lung function among Greek cotton industry workers: a cross-sectional study. The International Journal of Occupational and Environmental Medicine 2017;8(1):32-8.

[7] Ferris BG. Epidemiology standardization project (American Thoracic Society) Am Rev Respir Dis 1978;118(6 Pt 2):1-120.

[8] Pellegrino R, Viegi G, Brusasco V, et al. Interpretative strategies for lung function tests. Eur Respir J 2005;26(5):948-68.

[9] United States Department of Labour, Occupational Safety and Health Administration. Last accessed on 2014 Sep 22. https://www.osha.gov/SLTC/cottondust

[10] Zuskin E, Ivankovic D, Schachter EN, et al. A ten-year follow-up study of cotton textile workers. Am Rev Respir Dis 1991;143(2):301-5.

[11] Beck GJ, Schachter EN, Maunder LR, et al. A prospective study of chronic lung disease in cotton textile workers. Ann Intern Med 1982;97(5):645-51.

[12] Glindmeyer HW, Lefante JJ, Jones RN, et al. Exposurerelated declines in the lung function of cotton textile workers. Relationship to current workplace standards. Am Rev Respir Dis 1991;144(3 Pt 1):675-83.

[13] Bouhuys A, Zuskin E. Chronic respiratory disease in hemp workers. A follow-up study, 1967-1974. Ann Intern Med 1976;84(4):398-405.

[14] Suryakar AN, Katkam RV, Dhadke VN, et al. A study of oxidative stress in cotton industry workers from Solapur city. Biomed Res 2010;21(3):260-4.

[15] Su YM, Su JR, Sheu JY, et al. Additive effect of smoking and cotton dust exposure on respiratory symptoms and pulmonary function of cotton textile workers. Ind Health 2003;41(2):109-15.
[16] A Guide for persons employed in cotton dust environments. U.S. Department of Labor, Occupational Safety and Health Administration: U.S. Department of Health and Human Services (NIOSH) and NCDOL Personnel. 2007.

[17] Wang XR, Eisen EA, Zhang HX, et al. Respiratory symptoms and cotton dust exposure: results of a 15 year follow up observation. Occup Environ Med 2003;60(12):935-41.

[18] Altin R, Ozkurt S, Fisekçi F, et al. Prevalence of byssinosis and respiratory symptoms among cotton mill workers. Respiration 2002;69(1):52-6.

[19] Bünger J, Schappler-Scheele B, Hilgers R, et al. A 5-year follow-up study on respiratory disorders and lung function in workers exposed to organic dust from composting plants. Int Arch Occup Environ Health 2007;80(4):306-12.

[20] Christiani DC, Wang XR. Respiratory effects of longterm exposure to cotton dust. Curr Opin Pulm Med 2003;9(2):151-5.

[21] Schilling RS. Byssinosis in cotton and other textile workers. Lancet 1956;271(6938):319-24.

[22] Lai PS, Fresco JM, Pinilla MA, et al. Chronic endotoxin exposure produces airflow obstruction and lung dendritic cell expansion. Am J Respir Cell Mol Biol 2012;47(2):209-17.

[23] Wang X, Zhang HX, Sun BX, et al. Cross-shift airway responses and long-term decline in FEV1 in cotton textile workers. Am J Respir Crit Care Med 2008;177(3):316-20.

[24] Trupin L, Earnest G, San Pedro M, et al. The occupational burden of chronic obstructive pulmonary disease. Eur Respir J 2003;22(3):462-9.

[25] Aminian 0, Mozafari SAR, Haghighi KS, et al. Study of respiratory symptoms and pulmonary function in cotton textile workers. J Basic Appl Sci Res 2013;3(4):33-6.

[26] Kobayashi H, Kanoh S, Motoyoshi K, et al. Diffuse lung disease caused by cotton fibre inhalation but distinct from byssinosis. Thorax 2004;59(12):1095-7.

[27] Shi J, Mehta AJ, Hang JQ, et al. Chronic lung function decline in cotton textile workers: roles of historical and recent exposures to endotoxin. Environ Health Perspect 2010;118(11):1620-4.

[28] Chattopadhyay BP, Saiyed HN, Mukherjee AK. Byssinosis among jute mill workers. Ind Health 2003;41(3):265-72. 